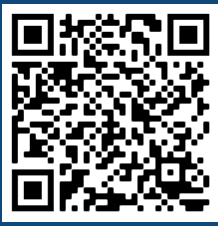

Keywords:

Single tree plot

Linear plot

Clonal test

Standard error

BLUP

Historic:

Received 01/01/2020

Accepted 0 I/05/2020

Correspondence:

Marcos Rafael Amânciola, Mateus Chagas Andrade ${ }^{2 a}$, João Gabriel Zanon Paludeto ${ }^{3 a}$, Matheus Perek ${ }^{3 b}$, Odair Bison ${ }^{4 a}$, Amanda Roberta Vergani ${ }^{4 b}$, Andrea Nogueira Dias ${ }^{3 c}$, Evandro Vagner Tambarussi ${ }^{2,3 \mathrm{~d}+}$

\title{
ACCURACY OF GENETIC PARAMETERS ESTIMATION AND PREDICTION OF GENOTYPIC VALUES IN EUCALYPTUS USING DIFFERENT PLOT TYPES
}

AMÂNCIO, M. R.; ANDRADE, M. C.; PALUDETO, J. G. Z.; BISON, O.; VERGANI, A. R.; DIAS, A. N.; TAMBARUSSI, E. V. Accuracy of genetic parameters estimation and prediction of genotypic values in Eucalyptus using different plot types. CERNE, v. 26,n. 4, p.482-490, 2020.

\section{HIGHLIGHTS}

With this study we addressed the uncertainties concerning the best plot design for evaluating clones for forest breeding.

Greater precision in clone selection is obtained with single-tree plot designs.

Greater heritability and selection accuracy are also obtained with the single-tree plot.

The single-tree plot design is economically advantageous and provides more genetic information than the linear plot design.

\section{ABSTRACT}

A suitable experimental design should control the environmental effect and be capable of discriminating genotypes. Two clonal tests of Eucalyptus were planted side by side in a randomized block design with the same 32 treatments under two different plot designs. The first trial was designed with five plants per plot (linear plot, LP) and six block replicates at a spacing of $3 \times 2 \mathrm{~m}$. The second trial was designed with one plant per plot (single-tree plot, STP) and 30 block replicates also at a spacing of $3 \times 2 \mathrm{~m}$. Diameter at breast height $(d b h)$, height $(h)$, and individual volume (vol) were measured at five years of age. The STP design presented broad-sense heritabilities values of 0.23 for $h$ and $0.4 \mathrm{I}$ for vol, which were higher than those found for the LP design ( 0.12 for $h$ and 0.22 for vol). The ratio between the standard error and the estimated genotypic variance $\left(\widehat{S}_{g}\right)$ was lower for the three evaluated traits in the STP trial. The correlations between the genetic values were positive and of high magnitude, ranging from $0.87(h)$ to 0.91 (vol), but there were many differences between the two designs with regard to the ranking of clones. The STP presented better discriminant power according to the biplot analysis, as well as more accurate and reliable estimates.

' Forest Resarch and Studies Institute, Monte Alegre, Piracicaba, São Paulo, Brazil, ORCID: 0000-0002-1638-2360ª 2 São Paulo State University, Botucatu, São Paulo, Brazil, ORCID: 0000-0003-38। 0-262Xa

3 Midwestern State University, Irati - Paraná, Brazil, ORCID: 0000-000 I-5647-65 I 6a, 0000-0003-09 I9-6874b, 0000-0002-772 I- | 856 , 0000-000 I-9478-5379d

4 Duratex Florestal Ltda. Agudos, São Paulo, Brazil ORCID: 0000-0002-6I24-9892a, 0000-0003-3670-4096 


\section{INTRODUCTION}

Eucalyptus is a very widely planted genus throughout the world. Species of Eucalyptus are grown for lumber, paper pulp, piling and posts, fuel wood, medicinal products, tannins, and oils and are also used as windbreaks and ornamentals.

Experimental trials are designed to take into account the evaluative components and to minimize spatial effects to obtain accurate predictions (De Faveri et al., 2016). In forest breeding programs, the planning of clonal and progeny tests presents several challenges to the researcher, specifically, the arrangement of the materials in trials, the selection of proper statistical tools for analyses, and the determination of both the plot size and the form and number of plants per plot (Steel and Torrie, 1980; Fins et al., 1992). These types of tests are necessary but are time-consuming and are associated with high costs (Zobel and Talbert, 1984; Jansson et al., 1998).

Because plant breeding trials are subject to variation due to the environmental effects in the field (Hunt et al., 20I2), the correct definition of the plot-type to be used in assays leads to more conclusive results. Tests with singletree plots (STPs) are commonly used because these plots require fewer resources and allow the assessment of a wide range of materials per unit of area, thus making a larger number of repetitions possible (Jansson et al., 1998; Gezan et al., 2006). In addition, some authors state that the use of smaller plots increases the statistical efficiency of the design, since with a smaller experimental unit, the blocks are also smaller, and as a result, more homogeneous (Lamberth and Gladstone, 1983; Fonseca et al., 2010; Rosado et al., 2012). In contrast, some authors affirm that plots with a higher number of plants, such as linear plots (LPs), allow more accurate estimations of genetic variability and genetic gains (Lin et al., 1993; Williams and John, 1996; Zhang et al., 2015).

Trials using plots with multiple plants per plot represent more closely the competition existing in operational plantations in traditional clonal forestry. In these plots, individuals compete with related and unrelated genotypes. In contrast, in STPs, estimation of traits such as volume and survival may be biased because of the asymmetric competition between divergent genotypes, causing border effects and possibly, biases (Zhang et al., 20I5).

Greater efficiency in genotype selection in tree breeding programs might result from a better understanding of the genotypic correlation between genetic material in different types of plots (Jansson et al., 1998; Gezan et al., 2006).

The objective of this study was to evaluate which plot-type, i.e., STP or LP, more accurately estimates the genetic parameters and has greater discriminant power with respect to genotypic performance.

\section{MATERIAL AND METHODS}

\section{Experimental data}

The data used in our work originated from two trials implemented in 2008. Both trials contain the same genetic material: $2 \mathrm{I}$ clones of Eucalyptus grandis W. Hill ex Maiden, 10 clones of the hybrid Eucalyptus urophylla $x$ Eucalyptus grandis, and one clone of Eucalyptus urophylla S.T. Blake, totaling 32 tested clones. The trials were planted side by side on the Rio Claro farm, where the soil type is Latosol Red Alico, sandy texture, with a flat relief and smooth undulating surface. The climate, according to the Köppen classification, is the $\mathrm{Cfb}$ type (subtropical humid mesoteric, with temperate climate). The annual average rainfall, recorded at Lençóis Paulista, state of São Paulo (22 $46^{\prime}$ '57'" S, 48 5 I' $33^{\prime \prime}$ W; altitude $697 \mathrm{~m}$ ) is I,483 mm. In order to verify the effect of the experimental design in the estimation of the genotypic variance components, the two trials were planted in two different designs. The first trial (LP) was set in a randomized block design with 32 treatments (five plants per plot, six replicates, and a spacing of $3 \times 2 \mathrm{~m}$ ). The second trial (STP) was set in a randomized block design with the same 32 treatments (one plant per plot, 30 replicates, with a spacing of $3 \times 2 \mathrm{~m}$ ).

\section{Statistical analysis}

\section{LP}

The evaluated traits were the diameter at breast height $(\mathrm{dbh}, \mathrm{cm})$, total height $(h, \mathrm{~m})$, and individual volume $\left(\mathrm{vol}, \mathrm{m}^{3}\right)$ at five years of age (cutting age). The mixed model used for the linear plots test was: where $y$ is the data vector, $b$ is the block replication vector (assumed to be fixed), $s$ is the species effect vector (assumed to be fixed ), $g$ is the genotypic effects vector (assumed to be random), $p$ is the interaction between block replication and clones (i.e., the plot vector, assumed to be random), and $e$ is the random vector of errors with homoscedastic distribution. $\mathbf{X}, \mathbf{U}, \mathbf{Z}$, and $\mathbf{W}$ represent the incidence matrices for the above cited effects.

$$
y=\mathbf{X} b+\mathbf{U} s+\mathbf{Z} g+\mathbf{W} p+e,
$$

STP

The mixed model used for the STP trial was: where $y$ is the data vector, $b$ is the block replication vector (assumed to be fixed), $s$ is the species effect 
vector (assumed to be fixed), $g$ is the genotypic effects vector (assumed to be random), and is the random vector of errors with homoscedastic distribution. $\mathbf{X}, \mathbf{U}$, and $\mathbf{Z}$ represent the incidence matrices for the above cited effects.

$y=\mathbf{X} b+\mathbf{U} s+\mathbf{Z} g+e$

All the statistical analyses were performed using the statistical environment $R$ (R Core Team, 2019). The variance components were estimated with the Restricted Maximum Likelihood (REML) method, using the Ime4 mixed model analysis package (Bates et al., 2015). The significance of the random effects was tested with the Likelihood Ratio Test (LRT), which uses a chi-square test with I degree of freedom. For the fixed effects, we used the $F$ test with the Satterthwaite approximation (Satterthwaite, 1946).

\section{Genetic parameter estimates}

We used the estimated variance components: $\hat{\sigma}_{g}^{2}=$ genotypic variance among the clones, $\hat{\sigma}_{p l o t}^{2}=$ variance among the plots, and $\hat{\sigma}_{e}^{2}=$ residual error variance, to estimate the phenotypic variance $\left(\hat{\sigma}_{P}^{2}\right)$ by: 3 for the LP assay and equation 4 for the STP assay.

$$
\begin{aligned}
& \hat{\sigma}_{P}^{2}=\hat{\sigma}_{g}^{2}+\hat{\sigma}_{p l o t}^{2}+\hat{\sigma}_{e}^{2} \\
& \hat{\sigma}_{P}^{2}=\hat{\sigma}_{g}^{2}+\hat{\sigma}_{e}^{2}
\end{aligned}
$$

The estimated genetic parameters were:

a) Broad-sense heritability 4

$\left(\hat{h}_{g}^{2}\right): \hat{h}_{g}^{2}=\frac{\hat{\sigma}_{g}^{2}}{\hat{\sigma}_{P}^{2}}$

b) Average clone heritability $\left(\hat{h}_{m}^{2}\right)$, for the LP assay: 5 and for the STP assay: 7 ; where is number of blocks and is number of plants per plot;

$\hat{h}_{m}^{2}=\frac{\hat{\sigma}_{g}^{2}}{\hat{\sigma}_{g}^{2}+\frac{\hat{\sigma}_{\text {plot }}^{2}}{b}+\frac{\hat{\sigma}_{e}^{2}}{n b}}$

$\hat{h}_{m}^{2}=\frac{\hat{\sigma}_{g}^{2}}{\hat{\sigma}_{g}^{2}+\frac{\hat{\sigma}_{e}^{2}}{b}}$

c) Coefficient of genotypic variation ); 7 where $\bar{x}$ is the average mean of clones;

$$
\left(\widehat{C V}_{g} \%\right): \widehat{C V}_{g}(\%)=\frac{\sqrt{\hat{\sigma}_{g}^{2}}}{\bar{x}} \cdot 100
$$

d) Coefficient of error variation .

$\left(\widehat{C V}_{e} \%\right): \widehat{C V}_{e}(\%)=\frac{\sqrt{\hat{\sigma}_{e}^{2}}}{\bar{x}} \cdot 100$
The approximate standard error $(\widehat{S e})$ was obtained using the breedR package (Muñoz and Sanches, 20I8), which makes use of the Al-REML algorithm and provides standard errors of both the variance components and heritability values by the inverse of the average information matrix provided by the methodology (Fischer et al., 2004).

With the aim of understanding the ability of the two designs to estimate the genotypic variance $\left(\hat{\sigma}_{g}^{2}\right)$ more accurately, we calculated a percentage ratio between the standard error and the corresponding 9 .

$\widehat{\sigma}_{g}^{2}$, defined $\widehat{S_{g}}(\%): \widehat{S_{g}}(\%)=\frac{\widehat{S e}}{\widehat{\sigma}_{g}^{2}} \cdot 100$

With the objective of measuring the correlation between the real and predicted genotypic values under unbalanced designs, the average accuracy of prediction $(\hat{r} \hat{g} g)$ was estimated as 10 , where is the prediction error variance and $\hat{\sigma}_{g}^{2}$ the genetic variance between genotypes (Resende and Duarte, 2007).

$\hat{r}_{g g}=\sqrt{1-\frac{P E V}{\hat{\sigma}_{g}^{2}}}$

Best Linear Unbiased Prediction (BLUP) estimates, correlations, and discriminant power

The predicted genetic values were obtained by the BLUP method and presented in three ways:

a) Composition of a double-entry matrix using the BLUPs of the variable vol $\left(\mathrm{m}^{3}\right)$ as rows and plot types as columns, with the objective of performing a GGEBiplot analysis, in order to determine the discriminant power and the representativeness for the two designs evaluated using the GGEBiplots package of R (Dumble et al., 2017).

b) Estimation of the Spearman correlations of BLUP between the evaluated traits in the two plot sizes, using the PerformanceAnalytics package (Peterson and Carl, 2019).

c) Ranking of the 20 best clones to evaluate the selection coincidence between the two experimental designs.

We also evaluated graphically the amount of shrinkage obtained on BLUP estimates of $\mathrm{vol}\left(\mathrm{m}^{3}\right)$ provided by the two experimental trials.

\section{RESULTS}

\section{Genetic parameters and standard errors}

From the statistical tests it can be verified that for the two trials, there were no statistically significant differences between species for all traits; however, the clone effect was significant (Table I). 
TABLE I Significance of random effects (Chi-squares - LRT test) and fixed effects (mean squares - F-test) of both models used in the analysis on diameter at breast height $(\mathrm{dbh}, \mathrm{cm})$, total height $(h, \mathrm{~m})$, and individual volume $\left(\mathrm{vol}, \mathrm{m}^{3}\right)$ of Eucalyptus spp. clones were evaluated at five years of age in two different experimental designs established at the study site, Lençóis Paulista, São Paulo State.

\begin{tabular}{ccccccc}
\hline \multirow{2}{*}{ Effect } & \multicolumn{3}{c}{ Linear plot (LP) } & \multicolumn{3}{c}{ Single tree plot (STP) } \\
\cline { 2 - 7 } & $\mathrm{dbh}$ & $\mathrm{h}$ & $\mathrm{vol}$ & $\mathrm{dbh}$ & $\mathrm{H}$ & vol \\
\hline \multirow{2}{*}{ Fixed } & $5.40^{\text {ns }}$ & $68.86^{* *}$ & $0.0 \mathrm{I}^{\text {ns }}$ & $5.59^{\text {ns }}$ & $20.93^{\text {ns }}$ & $0.0 \mathrm{I}^{\text {ns }}$ \\
& $5.57^{\text {ns }}$ & $14.7 \mathrm{I}^{\text {ns }}$ & $0.0 \mathrm{I}^{\text {ns }}$ & $14.39^{\text {ns }}$ & $25.60^{\text {ns }}$ & $0.0 \mathrm{I}^{\text {ns }}$ \\
\hline \multirow{2}{*}{ Random } & $44.740^{* *}$ & $28.55^{* *}$ & $59.38^{* *}$ & $248.18^{* *}$ & $146.74^{* *}$ & $284.63^{* *}$ \\
& $7.09^{* *}$ & $3.87^{*}$ & $7.29^{* *}$ & - & - & - \\
\hline
\end{tabular}

ns: not significant; ": significant at $5 \%$ probability; "*: significant at $1 \%$ probability.

The plot effect was significant in the LP design. The genotypic variance $\left(\hat{\sigma}_{g}^{2}\right)$ was superior for all traits in the STP design than in the LP design. The broadsense heritability $\left(\hat{h}_{g}^{2}\right)$ for the three evaluated traits was superior in the STP and ranged from $0.27(\mathrm{~h})$ to 0.40 (vol), while in the LP design, the values of this parameter ranged from 0.12 (h) to 0.22 (vol) (Table 2). The values of $\widehat{S_{g}}(\%)$ obtained in the STP design for the three evaluated traits ranged from $27.91 \%$ to $29.91 \%$ for vol and $h$, respectively (Table 2). On the other hand, in the LP test, the estimate ranged from $30.83 \%$ for vol, to $35.54 \%$ for $h$.

Similar to broad-sense heritability $\left(\hat{h}_{g}^{2}\right)$ the average heritability of clones $\left(\hat{h}_{m}^{2}\right)$ for the three traits evaluated (Table 2) was higher in the STP trial, ranging from 0.92 (h) to 0.95 (dbh and vol), whereas in the LP design, $\hat{h}_{m}^{2}$ varied from $0.80(h)$ to $0.88(\mathrm{vol})$.

The coefficient of genotypic variation $\left(\widehat{C V}_{g}(\%)\right)$ for the LP assay ranged from $7.27 \%$ to $26.41 \%$ for $h$ and vol, respectively. These values were lower than the values found for the STP trial, which varied from II.24\% (h) to $37.35 \%$ (vol). The coefficient of error variation $\left(\widehat{C V}_{g}(\%)\right)$ of the two evaluated trials presented similar values (Table 2).

The average accuracy of the prediction or theoretical accuracy $\left(\hat{r}_{\hat{g} g}\right)$ ranged from $0.86(h)$ to $0.92(\mathrm{vol})$ for the LP design and presented lower values than the $\hat{r}_{\hat{g} g}$ obtained with STP, which ranged from $0.95(h)$ to 0.97 (vol).

\section{Biplot analysis}

The biplot is environment-centered and environment-metric preserving, which means it is constructed strictly for environmental analysis, despite showing various genotypes (numbers within the circles). The interpretations are as follows (Yan and Tinker, 2006):

a) The lines that connect the biplot origin and the tested environments are called environment vectors, and the cosine of the angle between these vectors are the exact correlation between them.
TABLE 2 Estimation of genetic parameters, with standard errors $(\widehat{S e})$, for Eucalyptus spp. clones in the linear plot (LP) and single tree plot (STP) design established at the study site in Lençóis Paulista, São Paulo State, at five years of age. The traits evaluated include: diameter at breast height $(\mathrm{dbh})$, total height (h), and volume (vol).

\begin{tabular}{|c|c|c|c|c|c|c|}
\hline \multirow{2}{*}{ Parameters } & \multicolumn{3}{|c|}{ Linear plot (LP) } & \multicolumn{3}{|c|}{ Single-tree plot (STP) } \\
\hline & $\mathrm{dbh}$ & $\mathrm{h}$ & vol & $\mathrm{dbh}$ & $\mathrm{h}$ & vol \\
\hline \multirow{2}{*}{$\hat{\sigma}_{g}^{2}(\widehat{S e})$} & 2.85 & 2.76 & 2.98 & 6.31 & 6.69 & 5.66 \\
\hline & $(0.93)$ & $(0.98)$ & $(0.92)$ & $(1.77)$ & $(1.95)$ & (I.58) \\
\hline \multirow{2}{*}{$\hat{\sigma}_{p l o t}^{2}(\widehat{S e})$} & 1.10 & 1.20 & 0.89 & & & \\
\hline & $(0.47)$ & $(0.67)$ & $(0.37)$ & - & - & \\
\hline \multirow{2}{*}{$\hat{\sigma}_{e}^{2}(\widehat{S e})$} & 11.78 & 18.25 & 9.22 & 10.49 & $|8.2|$ & 8.37 \\
\hline & $(0.66)$ & $(1.03)$ & $(0.52)$ & $(0.54)$ & $(0.93)$ & $(0.43)$ \\
\hline$\hat{\sigma}_{P}^{2}$ & 15.74 & 22.15 & 13.10 & 16.80 & 24.90 & 14.03 \\
\hline \multirow{2}{*}{$\hat{h}_{g}^{2}(\widehat{S e})$} & 0.18 & & & 0.38 & 0.27 & 0.40 \\
\hline & $(0.05)$ & $(0.04)$ & $(0.05)$ & $(0.07)$ & $(0.06)$ & $(0.07)$ \\
\hline \multirow{2}{*}{$\hat{h}_{m}^{2}(\widehat{S e})$} & 0.85 & 0.80 & 0.88 & 0.95 & 0.92 & 0.95 \\
\hline & $(0.05)$ & $(0.06)$ & $(0.04)$ & $(0.01$ & $(0.02)$ & $(0.01)$ \\
\hline$\widehat{C V}_{g}(\%)$ & 11.02 & 7.27 & $26.4 I$ & 16.78 & 11.24 & 37.35 \\
\hline$\widehat{C V}_{e}(\%)$ & 22.39 & $|8.7|$ & 46.43 & 21.63 & 18.55 & $45.4 I$ \\
\hline$\widehat{S_{g}}(\%)$ & 32.58 & 35.54 & 30.83 & 28.05 & 29.13 & 27.91 \\
\hline$\hat{r}_{\hat{g} g}$ & 0.90 & 0.86 & 0.92 & 0.97 & 0.95 & 0.97 \\
\hline \multirow{2}{*}{$\bar{x}(S d)$} & 15.33 & 22.83 & 206.82 & 14.97 & 23.01 & 201.46 \\
\hline & $(3.91)$ & $(4.7 I)$ & $(0.1 \mathrm{I})$ & $(4.01)$ & $(4.94)$ & $(116.07)$ \\
\hline
\end{tabular}

$\hat{\sigma}_{g}^{2}$ : genotypic variance; $\hat{\sigma}_{\text {plot }}^{2}$ :variance due to plot effect; $\hat{\sigma}_{e}^{2}:$ residual variance; $\hat{\sigma}_{p}^{2}$ phenotypic variance; $\hat{h}_{g}^{2}$ : broad-sense heritability; $\hat{h}_{m}^{2}$ : average clone heritability; $\widehat{C V}_{g}(\%)$ : coefficient of genotypic variation; $\widehat{C V}_{e}(\%)$ : coefficient of error variation; $\widehat{S_{g}}(\%)$ : ratio between the standard error of estimate and the genotypic variance; $\hat{r}_{g g}$ : average accuracy of prediction; $\bar{x}$ : average mean with standard deviation.

b) The length of the vectors is associated with the standard deviation of the trait mean and it represents the discriminant power of a given environment, i.e., the ability of that environment to correctly discriminate the genotype performance. The concentric circles on the biplot help to visualize the length of these vectors.

The biplot method presented reliable results, since the first two first-principal components ( $\mathrm{PCl}$ and $\mathrm{PC2}$ ) explained I $00 \%$ of all variation in the BLUP (Figure I). The first principal component $(\mathrm{PCI})$ represents the row effect in the entry matrix, that is, the BLUP itself. The second principal component represents the variation associated with the interaction between the line and the column-in this case, between the BLUP and the environment.

It is possible to see that the STP design provides less BLUP shrinkage towards the mean than the LP design (Figure 2). This may be due to the LP trial having larger residual variance and a smaller number of replicates.

\section{DISCUSSION}

The significance of the clone effect (Table I) indicates that there is genotypic variance $\left(\hat{\sigma}_{g}^{2}\right)$ to be 


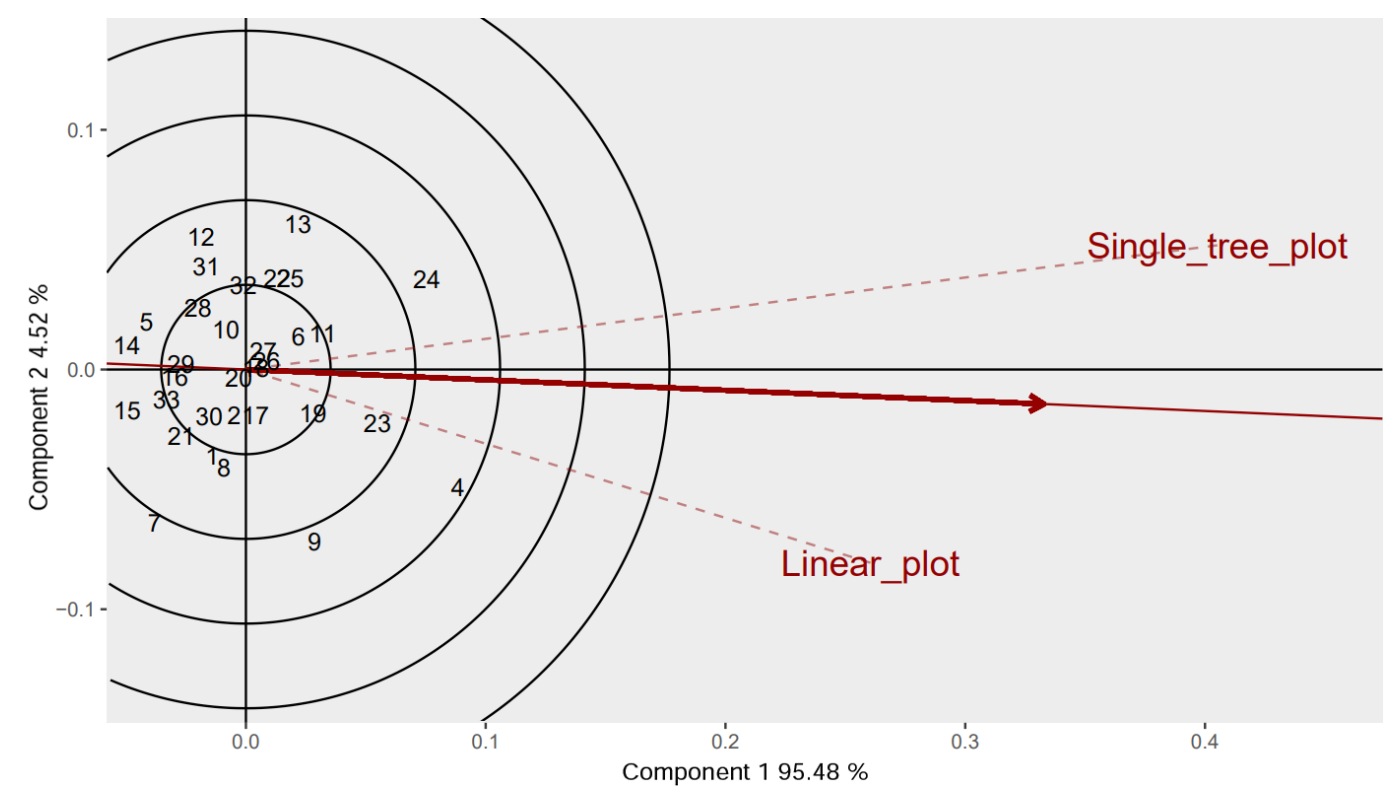

GGE Biplot showing components 1 and 2 explaining $100 \%$ of the total variation using Column Metric Preserving SVP and Tester-Centered G+GE with no scaling

FIGURE I GGE Biplot “Discriminant Power vs. Representativeness” generated with BLUP values from the individual volume of Eucalyptus spp. clones in the linear plot and single-tree plot designs at five years of age. The clones were established at the study site in Lençóis Paulista, São Paulo State.

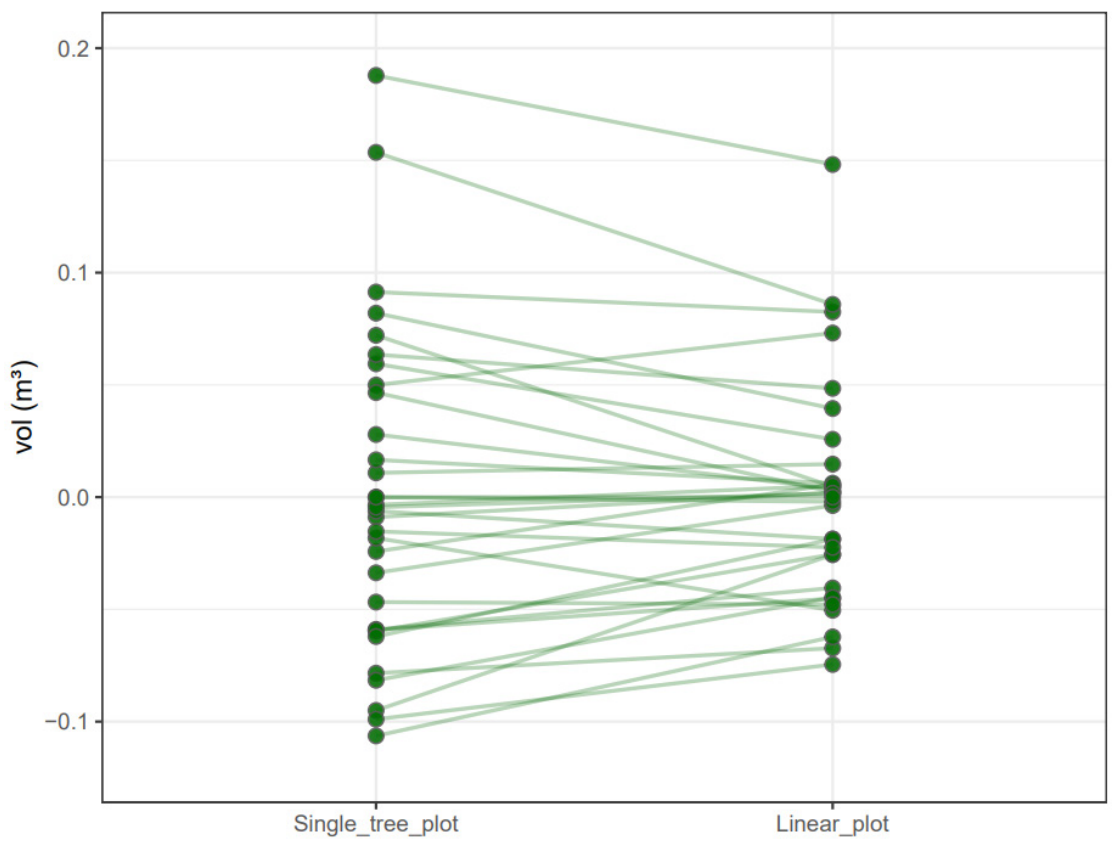

FIGURE 2 The shrinkage of BLUP from the individual volume of Eucalyptus spp. clones in the linear plot and single-tree plot designs at five years of age. The clones were established at the study site in Lençóis Paulista, São Paulo State.

explored, and therefore, a high possibility of gain with selection. However, we can observe higher values of $\hat{\sigma}_{g}^{2}$ in the STP trial than in the LP trial (Table 2). This may have occurred due to greater influence of allocompetition, in other words, a greater intergenotypic competition, which tends to force different responses of each genetic material and consequently inflates the variability between clones (Scarpinati et al., 2009, Silva et al., 2016).
The broad sense heritability $\left(\hat{h}_{g}^{2}\right)$ was superior in the STP trial, evidencing a greater possibility of gain in clone selection. Similar results were found by Scarpinati et al. (2009), who reported that this was probably due to the fact that the STP design has a lower environmental effect, since the tree is the plot itself. This behavior is also reported by Gezan et al. (2006), who concluded that the use of a STP design provides a more effective 
sampling of the environmental variation, reducing it significantly. The fact that the plot effect was statistically significant in the present study (Table I) corroborates these findings.

When using the average heritability $\left(\hat{h}_{m}^{2}\right)$ of clones as a selection parameter, there is a greater possibility of gain through the STP assay, due to the high values of $\hat{h}_{m}^{2}$ (Table 2). This result is directly related to the number of repetitions, which is higher in the STP trial than in the LP trial, allowing the experimental error to be diluted in the ratio between the residual variance and the number of repetitions. As described by Costa et al. (2005), the highest number of repetitions and plots with the smallest number of individuals result in a greater reliability of the estimates. The higher values of the coefficient of genotypic variation $\left(\widehat{C V}_{g}(\%)\right)$ found for the STP trial are closely related to its greater ability to discriminate the superior genotypes and may also be associated with the fact that the STP design has a greater number of block replicates, which consequently causes the evaluated clones to be more spaced through the whole experiment, as the STPs cover a much larger area than the LPs. The LP design, in turn, comprised five or more clones in a single place, with a much smaller number of block replicates. According to Grondona et al. (1996), the presence of environmental heterogeneity tends to inflate the residual variation due to the variation of treatments being confounded with other sources of variation, such as environmental variation. In other words, greater spatialization may be responsible for diluting the environmental effects and consequently capturing genetic variation with less noise, directly reflecting the higher values of broad-sense heritability $\left(\hat{h}_{g}^{2}\right)$ that were found.

The average information matrix, also known as Fisher's information matrix, provides a measure of the amount of information that the data can provide about the parameters that the model seeks to estimate. The more informative the data, the greater the accuracy of the estimate $\left(\hat{r}_{\hat{g} g}\right)$, and consequently, the lower the standard error (Chao et al., 2017). The standard error gives us an idea of the reliability in the estimation of variance components. Based on this assumption, in order to indicate the imprecision associated with the estimation of the genotypic variance in both trials, as well as to standardize this error for subsequent comparisons, $\widehat{S_{g}}(\%)$ was estimated.

Using $\widehat{S_{g}}(\%)$, we can state which experimental design provides genotypic variance estimates that are more concise and accurate. The estimates in the STP trial presented lower values of $\widehat{S_{g}}(\%)$ and therefore, are more accurate than the estimates in the LP trial. The theoretical accuracy $\left(\hat{r}_{\hat{g} g}\right)$ derived from the prediction error variance (PEV) also corroborates the superiority of the estimates provided by the STP design, since this design presented the highest values of this estimate (Table 2). This higher accuracy is probably associated with the diluted environmental effects due to the greater number of block replications, as previously stated. These "cleaner" estimates of genotypic variance increase both the discriminant power of the design (Figure I), as well as the magnitude of the genotypic variance itself, resulting in higher and better estimated values of $\widehat{C V}_{g}(\%)$ and $\hat{h}_{g}^{2}$. The use of an STP design is efficient and accurate in assessing the true genetic variation with respect to progeny or clonal tests for species of the Eucalyptus genus (Silva et al., 2016). Increasing the number of replications to the detriment of plot size tends to increase the accuracy of the estimates because it allows a more efficient sampling of the environment and reduces the residual variance (Resende, 1995, Gezan et al., 2006).

A biplot is constructed by plotting the first two principal components, PCl and PC2. These two components are associated with the row and column effect of the input matrix, respectively, i.e., the percentage of the explained variation. The magnitude of the value indicates the influence of the effect, since the singular value of a principal component is the square root of the sum of squares explained by that principal component (Yan and Hunt, 2002). Therefore, it can be stated that $95.48 \%$ of the variation contained in the genetic material is because of the matrix line, that is, of the genotype (BLUP) itself. The variation associated with PC2 (4.52\%) is due to the effect of the interaction between BLUP and environment, but since the experiments are spatially located side by side, this difference can be attributed to the experimental design, i.e., the plot type. All the variation was explained by these two principal components (100\%), similar to the result reported by Granato et al. (2016), where the authors argued that this result is due to having analyzed only two environments. Although it is unusual, this phenomenon probably also occurred in our study, since we analyzed two very identical environments that only differ with regard to the plot type used.

The biplot presented in Figure I represents the discriminant power of the environment. The length of the vector in a biplot is proportional to the standard deviation within a respective environment; therefore, the biplot is a way of measuring the discriminant ability, in other words, the ability of a given environment to accurately 
inform which genotypes are genetically superior (Yan and Tinker, 2006). Although the two trials are positively and highly correlated (0.9I), the STP design presented a larger vector compared to the LP trial, meaning that the STP design has a greater discriminant power, and therefore, greater power to identify which genotypes are effectively superior. This result corroborates the discussions about $\widehat{S}_{g}(\%), \widehat{C V}_{g}(\%), \hat{r}_{\hat{g} g}$, and $\hat{h}_{g}^{2}$.

Phenotypic measurements are composed of genetic effects and environmental noise, and models are used to specify, represent, and quantify those underlying effects. We also know that when there is high environmental noise, there is less genetic information available for us to assess (White et al., 2007). One way to handle this environmental noise is to use shrinkage estimators, such as BLUP. The shrinkage is actually a desirable property of BLUP estimates, since it adjusts individuals with extreme performances (high or low) towards the mean when the statistical power is low, thus increasing prediction accuracy (Piepho et al., 2008).

The shrinkage only acts when there is environmental noise (unbalanced data), and the amount of shrinkage is proportional to the noise itself. In other words, the larger the residual variance, i.e., environmental noise, the larger the shrinkage effect on the predicted breeding values (Hill and Rosenberger, 1985, Follmann et al., 2019). Therefore, it is safe to say that because there is less environmental noise in the STP design than in the LP design, there is less shrinkage in the BLUP estimates (Figure 2). This also facilitates the selection of superior genotypes and can thus, be seen as another measure of discriminant ability, like the length of the vector in the biplot (Figure I).

In the genotype ranking in the two trials (Table 3), diameter at breast height $(\mathrm{dbh})$ and individual volume (vol) presented 18 coincident clones in the selection, which represents $90 \%$ of coincidence between the two experimental design methods. For height $(h), 16$ clones coincided, indicating $80 \%$ of coincidence. Similar results were found by Scarpinati et al. (2009), who also found high agreement between the selection of different experimental designs. Stanger et al. (20II) reported similar results, observing that the ranking of hybrid Eucalyptus clones at the rotation age remains stable in STP and LP designs.

It is worth mentioning the behavior of clone 13 for the evaluated traits, which was ordered as the 6th (dbh) and 5th ( $h$ and vol) best in the STP design, however, for LP, it was ordered as the 9th (h), 12th (vol) and even I8th (dbh) best clone. This behavior may be attributed to the higher
TABLE 3 Comparison of the ranking of the 20 best clones in the two experimental designs for the traits diameter at breast height $(d b h)$, total height $(h)$, and individual volume ( $\mathrm{vol}$ ) in Eucalyptus spp. at 5 years of age. The clones were established at the study site in Lençóis Paulista, São Paulo State and are numbered from I to 32 .

\begin{tabular}{|c|c|c|c|c|c|c|}
\hline \multirow{2}{*}{ Ranking } & \multicolumn{2}{|c|}{$\mathrm{dbh}$} & \multicolumn{2}{|c|}{$\mathrm{h}$} & \multicolumn{2}{|c|}{ vol } \\
\hline & STP & LP & STP & LP & STP & LP \\
\hline I & $4^{*}$ & 4 & $4^{*}$ & 4 & $4 *$ & 4 \\
\hline 2 & $24 *$ & 23 & $24 *$ & 23 & $24 *$ & 24 \\
\hline 3 & $23 *$ & 24 & II* & 24 & $23 *$ & 23 \\
\hline 4 & II* & 9 & $19 *$ & 9 & $11 *$ & 9 \\
\hline 5 & $19 *$ & 19 & $13 *$ & 11 & $13 *$ & 19 \\
\hline 6 & $13 *$ & 11 & 6* & 19 & $19 *$ & II \\
\hline 7 & 6* & 17 & 9* & 6 & 6* & 6 \\
\hline 8 & $22 *$ & 6 & $23 *$ & 18 & 9* & 17 \\
\hline 9 & $9 *$ & 26 & $18 *$ & 13 & $22 *$ & 18 \\
\hline 10 & $25^{*}$ & 20 & $25 *$ & 8 & $25 *$ & 8 \\
\hline 11 & $17^{*}$ & 25 & 22 & 1 & $18 *$ & 26 \\
\hline 12 & $18 *$ & 1 & $17^{*}$ & 25 & $17 *$ & 13 \\
\hline 13 & $20 *$ & 27 & $32 *$ & 17 & $33 *$ & 25 \\
\hline 14 & $26 *$ & 2 & 2 & 20 & $20 *$ & 22 \\
\hline 15 & $2^{*}$ & 18 & $20 *$ & 32 & $26 *$ & 2 \\
\hline 16 & $33^{*}$ & 8 & 12 & 33 & $27^{*}$ & 27 \\
\hline 17 & $10 *$ & 33 & $27^{*}$ & 27 & $10 *$ & 33 \\
\hline 18 & $27 *$ & 13 & $33 *$ & 26 & $2 *$ & 20 \\
\hline 19 & 32 & 22 & 10 & 30 & 32 & I \\
\hline 20 & 12 & 10 & $26 *$ & 7 & 12 & 10 \\
\hline
\end{tabular}

*Coincident clones in both rankings.
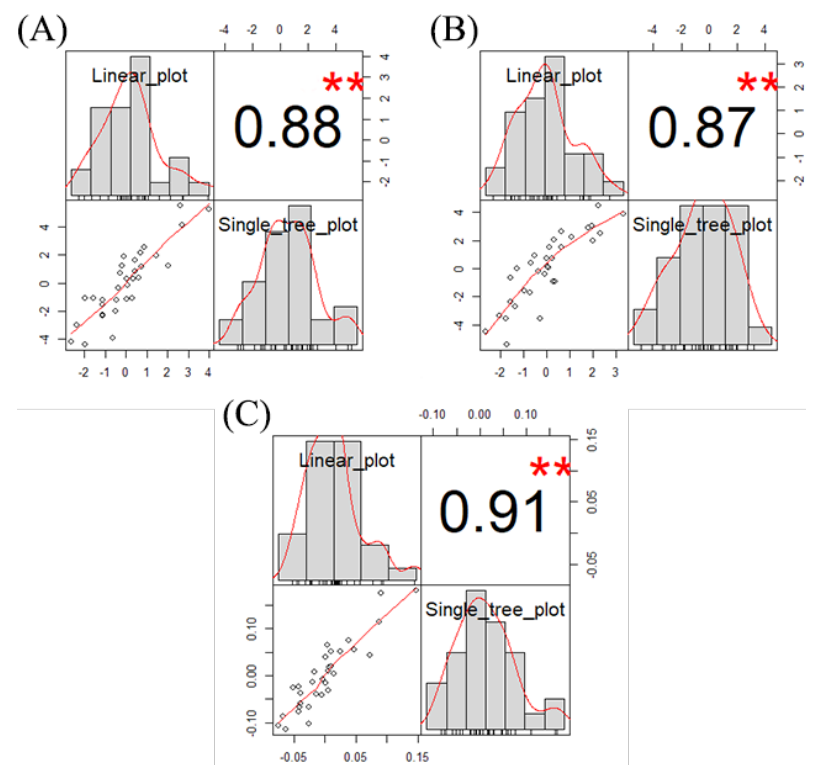

FIGURE 3 Estimates of BLUP correlations using the Spearman correlation coefficient for the traits diameter at breast height $(d b h, A)$, total height $(h, B)$, and individual volume ( $\mathrm{vol}, \mathrm{C}$ ) between the clones of the two Eucalyptus spp. evaluated at five years of age. The clones were established at the study site in Lençóis Paulista, São Paulo State. 
allocompetition in STP, which can result in different responses of certain genetic materials, as discussed previously.

Even though there were some changes in the ranking of clones, the correlations between the BLUP values for all the traits in both plot designs were high and significant (Figure 3).

Our study presented higher correlations than those reported in the study by Zhang et al. (2015), in which the authors found a moderate correlation (0.6I) for individual volume in Pinus spp. between the predicted genotypic values obtained for STPs and a trial with multiple plants per plot. Studying Eucalyptus globulus Labill, Callister et al. (2013) reported high genotypic correlation values for individual volume (0.90) between the STP and LP designs; this finding agrees with the results of our study. Despite the parameter estimates for the STP design being slightly better than those for LP, we can affirm that due to the high and positive correlations we found between BLUP values, both designs provide similar results.

Considering the costs of implementation and operation, the STP design tends to be commonly used in clonal test evaluation because the decrease in the number of plants and size of the plots can increase the prediction accuracy $\left(\hat{r}_{\hat{g} g}\right)$ and also lead to savings without damage to the selection (Gomes and Couto, 1985). However, it is worth mentioning that in STPs, all plants should be identified for later evaluation, while for the trials in the LPs, only the first plant of each plot can be identified, which makes it easier to put together the experimental sketch in the tree nursery and in planting. Another advantage of the LP design is the ease with which the breeder (or any other person, such as a manager) can visualize the superiority of a particular clone, since they are divided into plots and not mixed throughout the test.

Again, from an economic point of view, the STP design, by using the tree itself as experimental unit, allows a better effective use of the planting area. Unlike the case for LPs, with the STP design, breeders can test a greater number of clones in a larger number of replicates (Jansson et al., 1998). This enables more efficient resource allocation, which is of extreme interest in genetic experiments (Namkoong, 1979).

\section{CONCLUSIONS}

The STP design has greater discriminant power, presents more accurate estimates, and allows a better effective use of the planting area than the LP design. Although there is a high positive correlation between the BLUP estimates from the STP and LP trials, there were many differences between the two designs with regard to the ranking of the Eucalyptus clones.
Based on the results of this study, we recommend the use of the STP design in Eucalyptus breeding programs, as this will provide more accurate estimates and improved selection of superior genetic material for the purpose of forest breeding.

\section{ACKNOWLEDGEMENTS}

To Duratex for the experiment deployment and the data. João Gabriel Zanon Paludeto, Mateus Chagas Andrade and Matheus Perek were supported by CAPES Master's Degree scholarship. Professor Evandro Vagner Tambarussi, Ph.D. is supported by a National Counsel of Technological and Scientific Development (CNPq) research fellowship (Project n. 304899/2019-4).

\section{REFERENCES}

BATES, D.; MAECHLER, M.; BOLKER, B.; WALKER, S. Fitting linear mixed-effects models using Ime4. Journal of Statistical Software, v. 67, n. I, p. I-48, 2015.

CALLISTER. A.; ENGLAND, N.; COLLINS, S. Predicted genetic gain and realised gain in stand volume of Eucalyptus globulus. Tree Genetics \& Genomes, v. 9, p. 36I-375, 2013.

CHAO, J.; WARD, E. S.; OBER, R. J. Fisher information theory for parameter estimation in single molecule microscopy: tutorial. Journal of the Optical Society of America, v. 33, n. 7, p. 36-57, 2016.

DE FAVERI, J.; VERBYLA, A. P.; CULLIS, B. R.; PITCHFORD, W. S.; THOMPSON R. Residual variance-covariance modelling in analysis of multivariate data from variety selection trials. Journal of Agricultural, Biological and Environmental Statistics, v. 22, n. I, p. I-22, 2016.

COSTA, R. B.; RESENDE, M. D. V.; MORAES E SILVA, V. S. Experimentação e seleção no melhoramento genético de teca (Tectona grandis L. f.). Floresta e Ambiente, v. I4, n. I, p. 76-92, 2007.

DUMBLE, S.; BERNAL, E. F; VILLARDON, P. G. GGEBiplots: GGE Biplots with “ggplot2". R. package version 0.I.I. 2017. https://cran.r-project.org/package=GGEBiplots.

FINS L.; FRIEDMAN, S. T.; BROTSCHOL, J. V. Handbook of quantitative forest genetics. Springer Science \& Business Media, v. 39, 1992. 406p.

FISCHER, T. M.; GILMOUR, A. R.; VAN DER WERF, J. H. Computing approximate standard errors for genetic parameters derived from random regression models fitted by average information REML. Genetics Selection Evolution, v. 36, n. 3, p. 363-369, 2004.

FOLLMAN, D. C.; SOUZA, V. Q.; CARGNELUTTI FILHO, A.; DEMARI, G. H.; NARDINO, M.; OLIVOTO, T.; CARVALHO, I. R. Agronomic performance and genetic dissimilatrity of second-harvest soybean cultivars using REML/BLUP and Gower's algorithm. Bragantia, v. 78, n. 2, p. 197-207, 2019 
FONSECA, S.; RESENDE, M. D. V.; ALFENAS, A.; GUIMARÃES L.; ASSIS, T.; GRATTPAGLIA, D. Manual prático de melhoramento genético do eucalipto. Viçosa: UFV, 2010. 200p.

GEZAN, S. A.; WHITE, T. L.; HUBER, D. A. Comparison of experimental designs for clonal forestry using simulated data. Forest Science, v. 52, n. I, p. 108-I I6, 2006.

GOMES, F. P.; COUTO, H. T. Z. O tamanho ótimo de parcelas experimentais para ensaios com Eucaliptos. Circular Técnica do IPEF, v. 3I, p. 75-77, 1985.

GRANATO, I. S. C.; FRITSCHE-NETO, R.; RESENDE, M. D. V.; SILVA, F. F. Effects of using phenotypic means and genotypic values in GGE biplot analyses on genotype by environment studies on tropical maize (Zea mays). Genetics and Molecular Research, v. I4, n. 4, 2016.

GRONDONA, M. O.; CROSSA, J.; FOX, P. N.; PFEIFFER, W. $\mathrm{H}$. Analysis of variety yield trials using two-dimensional separable ARIMA processes. Biometrics, v. 52, n. 2, p. 763-770, 1996

HILL, R.; ROSENBERGER, J. Methods for combining data from germplasm evaluation trials. Crop Science, v. 25, n. 3, p. 467-470, 1985.

HUNT, C. H.; SMITH, A. B.; JORDAN, D. R.; CULLIS, B. R. Predicting additive and non-additive genetic effects from trials where traits are affected by interplot competition. Journal of Agricultural, Biological and Environmental Statistics, v. I8, n. I, p. 53-63, 2012.

JANSSON, G.; DANELL, Ö.; STENER, L. Correspondence between single-tree and multiple-tree plot genetic tests for production traits in Pinus sylvestris. Canadian Journal of Forest Research, v. 28, n. 3, p. 450-458, 1998.

LAMBERTH, C. C.; GLADSTONE, W. I. Statistical efficiency of row and noncontiguous family plots in genetic test of Loblolly pine. Silvae Genetica, v. 32, n. I-2, p. 24-28, 1983.

LIN, C. S.; BINNS, M. R.; VOLDENG, H. D.; GUILLEMETTE, R. Performance of randomized block designs in field experiments. Agronomy Journal, v. 85, n. I, p. I68-I7I, 1993.

MUÑOZ, F.; SANCHEZ, L. breedR: Statistical Methods for Forest Genetic Resources Analysts. R package version 0.12-2. 2018. https://github.com/famuvie/breedR.

NAMKOONG, G. Introduction to quantitative genetics in forestry. USDA Forest Service Technical Bulletin, 1979. 342p.

PETERSON, B. G.; CARL, P. PerformanceAnalytics: Econometric tools for performance and risk analysis. $\mathrm{R}$ package version 2.0.4. 2019. https://cran.r-project.org/ package $=$ PerformanceAnalytics.

PIEPHO, H. P.; MÖHRING, J.; MELCHINGER, A. E.; BÜCHSE, A. BLUP for phenotypic selection in plant breeding and variety testing. Euphytica, v. I6I, n. I-2, p. 209-228, 2008.
R Core Team. R: A language and environment for statistical computing. R Foundation for Statistical Computing Vienna, Austria, 2019

RESENDE, M. D. V. Delineamento de experimentos de seleção para maximização da acurácia seletiva e do progresso genético. Revista Árvore, v. 19, n. 4, p. 470-500, 1995.

RESENDE, M. D. V.; DUARTE, J. B. Precisão e controle de qualidade em experimentos de avaliação de cultivares. Pesquisa Agropecuária Tropical, v. 37, n. 3, p. I82-194, 2007.

ROSADO, A. M.; ROSADO, T. B.; ALVES, A. A.; LAVIOLA, B. G.; BHERING, L. L. Seleção simultânea de clones de Eucalyptus de acordo com produtividade, estabilidade e adaptabilidade. Pesquisa Agropecuária Brasileira, v. 47, n. 7, p. 964-97I, 2012.

SATTERTHWAITE, F. E. An approximate distribution of estimates of variance components. Biometrics Bulletin, v. 2, n. 6, p. II0-114, 1946.

SCARPINATI, E. A.; PERECIN, D.; PAULA, R. C.; BONINE, C. A. V.; PAVAN, B. E.; CANDIDO, L. S. Influência do modelo de análise estatística e da forma das parcelas experimentais na seleção de clones de Eucalyptus spp. Revista Árvore, v. 33, n. 4, p. 769-776, 2009

SILVA, W. M.; MORAES, M. L. T.; PUPIN, S.; SILVA, J. M.; SEBBENN, A. M.; PAVAN, B. E. Influência do tamanho de parcelas experimentais na seleção de progênies de $E$. camaldulensis Dehnh. Scientia Forestalis, v. 44, n. I02, p. 979-986, 2016

STANGER, T. K.; GALLOWAY, G. M.; RETIEF, E. C. L. Final results from a trial to test the effect of plot size on Eucalyptus hybrid clonal ranking in coastal Zululand, South Africa. Southern Forests: a Journal of Forest Science, v. 73, n. 3-4, p. $|3|-135,201 \mid$.

STEEL, R. G. D.; TORRIE, J. H. Principles and procedures of statistic: a biometrical approach. Mc Graw - Hill Book Company, 1980.633p.

WHITE, T. L.; ADAMS, W. T.; NEALE, D. B. Forest Genetics. CABI International, 2007. 66Ip.

YAN, W.; HUNT, L. A. Biplot analysis of diallel data. Crop Science, v. 42, n. I, p. 21-30, 2002.

WILLIAMS, E. R.; JOHN, J. A. Row- column factorial designs for use in agricultural field trials. Journal of the Royal Statistical Society, v. 45, n. I, p. 39-46, 1996.

YAN, W.; TINKER, N. A. Biplot analysis of multi-environment trial data: Principles and applications. Canadian Journal of Plant Science, v. 86, n. 3, p. 623-645, 2006.

ZHANG, J.; PETER, G. F; POWELL, G. L.; WHITE, T. L.; GEZAN, S. A. Comparison of breeding values estimated between single-tree and multiple-tree plots for a slash pine population. Tree Genetics \& Genomes, v. I I, n. 48, 20 I 5.

ZOBEL, B. J.; TALBERT, J. T. Applied forest tree improvement. John Wiley \& Sons, 1984. 505p. 